\title{
The Impact of Linguistic and Cultural Competence on Translation Quality: Pedagogical Insights into Translation Problems
}

\author{
Safiah Ali M. Asiri \\ Faculty of Languages and Translation, King Khalid University, KSA \\ Amal Abdelsattar Metwally \\ Faculty of Languages and Translation, King Khalid University, KSA
}

\begin{abstract}
The act of translation inside classroom undertakes a great deal of students' mistakes either grammatical or lexical (i.e. metaphoric, idiomatic, collocational) and some feedback as well. Many studies have concentrated on studying the reasons behind committing such mistakes on the level of undergraduates. However, this paper will start with shedding light on some samples of students' mistakes to reach instructorperspective proposed solutions at the end. The study aims at assisting both instructors and institutions of translation to apply pedagogical solutions to their students or translation courses. Moreover, the study further attempts to explore the impact of students' cultural and linguistic competence on the quality of translation. Researchers adopted a selective analytical method, mainly quantitative, in studying students' mistakes in the course of Translation 2 in the $1^{\text {st }}$ semester during the academic year 2019-2020 at the English Department Female Division - Faculty of Languages and Translation - King Khalid University, and then proposed solutions. The language pair discussed here is Arabic-English-Arabic.
\end{abstract}

Index Terms - translation problems, cultural competence, linguistic competence, translation quality, timed assessments, pedagogy

\section{INTRODUCTION}

This study explores the extent to which students enrolled in translation courses at the faculty of languages and translation at King Khalid University are aware of the linguistic and cultural competence and the role such competence plays in producing high quality target texts. The present paper asserts that the ability to promote students' translation competence is the most important aspect in translation education. In the light of the previous research, the present study investigates the pedagogical implications of the linguistic and cultural competence on the quality of translation towards producing self-directed, autonomous and competent translators.

\section{LITERATURE REVIEW}

This literature review explores the notions of linguistic and cultural competence in relation to translation towards training translation students to become professional translators. Many studies highlight the significance of translation competence and its role in producing translations of high quality. Madkour (2018) examines the impact of culture and intercultural competence on the performance of students in translation. Rafieyan (2016) explores the relationship between cultural intelligence and translation of culture-bound texts. This study asserts that cultural intelligence is supposed to be of great influence to the development of intercultural competence. The pedagogical implications of the findings of this study suggest incorporating cultural components of source language community into translation courses. Popescu (2011, p. 1183) addresses the issue of linguistic competence versus translation competence as a pedagogical approach. In (2013), Popescu conducted a research on the impact of language learning process on developing English linguistics of students' translation competence. Malyuga, Krouglov and Tomalin (2018) investigate the linguo-cultural competence as a cornerstone of translators' performance in the domain of intercultural business communication. Jibreel, Al-Abbasi and Al-Maqaleh (2017) investigate the relationship between translation strategies awareness and students' translation quality.

Other studies review errors commonly committed by translation students to look for appropriate solutions. Wongranu (2017) explores the types and causes of errors in translation made by English major students. The findings of this study suggest that students' anxiety and low self-confidence are primary causes of errors in translation. The students were found to employ "read-and-translate" procedure and showed carelessness during the process of translation. Rahmatillah (2013, p. 14) investigates translation errors in the process of translation where errors were found to be due to linguistic cultural competence deficiencies. 
It follows that a gap in the literature that this paper is designed to fill is how to enhance translation students' linguistic and cultural competence in order to be capable of producing high-quality translations.

\section{A. Translation}

Newmark (1998) defines translation as the act of "rendering the meaning of a text into another language in the way that the author intended the text" (as cited in Hartono, 2017, p.10). Bassnet and Guire (1991) state that translation is the substitution of target language meaning from source language meaning through linguistic studies and the target language culture. They conclude that the essence of translation lies on meaning. Blum-Kulka (1986 as cited in Madkour, 2018, p. 94) defines translation as an act of communication, and that the process of translation cannot be restricted to two languages as it also involves two cultures. Nida and Taber (as cited in Nord, 1997, p. 7) state that translating consists of reproducing in the receptor language the closest natural equivalent of the source language message.

From the above investigation of translation as defined by various scholars, it appears that adhering to the contextual meaning as intended by the author as well as having cultural knowledge of the two languages are of vital role in the production of faithful translation.

\section{B. Translation Competence}

It was Chomsky (1965) who first made a distinction between competence and performance. For him, competence is the system of linguistic knowledge, while performance is the way the language system is used in communication. In linguistics, Chomsky (1965) explains competence in terms of the use of intrinsic abilities to learn a language. In translation, Baker (1992) argues that a competent translator must have knowledge about the semantics and lexical rules of the source language. Cultural competence, on the other hand, refers to the awareness that develops out of the experience of culture (Madkour, 2018, p. 99).

The relationship between translation competence and linguistic and cultural competence has been addressed by various researchers, however, with different implications. An important challenge in the translation process is to find an appropriate equivalent that conveys the meaning of the source language. Consequently, failure to employ the accurate equivalent is a failure to translate which leads to communication gap and inadequacy. Students are usually facing the challenge of choosing between two or more words, and they are in a dilemma to adhere to the adequate contextual meaning. Unless teachers work on improving their students' competence, the students will be facing many problems in translation.

According to Spolsky's (1972) research, linguistic competence "is not enough for practical or educational purposes; we are interested not just in the fact that someone knows a language but that he knows how to use it". For this reason, students should be exposed to different language forms in real- life contexts and should develop a cultural background competence of the source and target language texts.

According to Pym (1992) translation competence is "the ability to generate a target text series of more than one viable term for a source text". This ability to select only one target text from this series to propose as a replacement of the source text is a significant proof of the translator's competence.

The above review of previous studies on translation competence reveals that translation competence cannot be achieved unless a translator possesses a good linguistic as well as cultural knowledge of the SL and TL (fig. 1). For this reason, translation students should be able to figure out the impact of such competence on their translation quality. Students of translation should be introduced to the commandments of professional translators from the very beginning of their translation courses in order to have the necessary awareness to work on their translation competence.
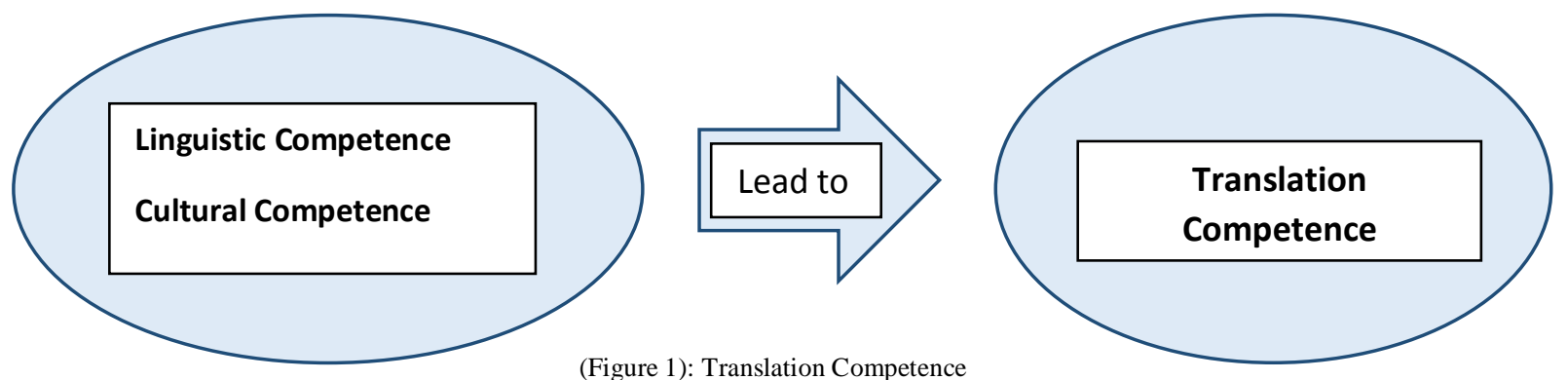

\section{Culture and Translation}

The Skopos theory, puts forward in "Ground-work for a General Theory of Translation" by Reiss \& Vermeer in 1984, emphasizes the functionality to achieve purpose of the target text in the target culture. According to the functional approaches to translation, there are three vital rules in the skopos theory, namely, the skopos rule, coherence rule and loyality rule. Skopos rule is to translate in a way which helps the translation to function in an appropriate way for the people who will use it (Reiss \& Vermeer, 1984). The translator is the one who will determine as for which particular skopos (i.e. purpose) should be the one to carry out in a translation process. The coherence rule implies that the translated text should make sense in the communicative situation in which it is delivered (Reiss \& Vermeer, 1984, p. 
113). The third principle of the skopos theory is loyalty principle. It refers to the responsibility the translator has toward the source text, target audience and other agents in the translational environment. This principle demands the translator to be loyal to the source text writer and the target readers, but this does not mean that the translator has always to follow (TL) receivers' expectations (Nord, 2001, p. 125). This also conforms to Venuti's (1995) notion of the invisibility of the translator. Since any translation generally involves various purposes, different strategies have to be taken in order to achieve each of them (as cited in Metwally, 2019, p. 385).

Many researches in the field of translation (Vermeer 1978, Hewson and Martin 1991) describe the translator as a "cultural operator", "bi-cultural" expert, and cross-cultural specialist". These studies reveal that cultural competence has a great impact on the quality of translation. Bassnett and Lefevere (2016) describe translation as a "cultural turn", while Venuti (2017) describes translation as a task of "transmitting culture". Additionally, many studies highlight the role of culture in translation. Madkour (2018) asserts that a shift in the purpose of translation necessitates training the students to acquire socio-cultural skills by engaging them in discussions about the culture of the original texts (p. 93). According to this study, understanding the cultural aspects of original texts is essential for "bridging the gaps between different cultures to grasp the core message of the text" and render the message of the text effectively. In this respect, Bhabha (1994) states that translation is "the nature of cultural communication" (p. 228).

\section{Errors in Translation}

Many research papers in the literature of translation studies have investigated the types and causes of translation errors. Baker (1992, p.20-21) maintains that translation errors are produced mainly by non-equivalence between the SL (source language) and TL (target language).

Translation errors are caused by a lack of comprehension of the source text, or misuse of words (Hatim, 2001). In this respect, Pym (1992) confirms that there are two types of translation errors. These are "binary and non-binary errors". "Binary errors" refer to any errors that are regarded as incorrect translation. On the contrary, "non-binary errors" refer to a translation that is not totally wrong, and could be improved. Binary errors imply that language competence needs to be improved, while non-binary errors reflect translation competence, which is defined by Pym as the ability to create a group of target texts, and then select the best one that suits purposes and readers (Wongranu, 2017, p. 118).

This review of how linguists classify and look at translation errors shows that there are many aspects involved in the translation process. In this study, the focus is on examining linguistic and cultural errors in students' translations towards promoting translation competence. Cultural errors could occur due to inadequate reproduction of culturespecific expressions, while linguistic translation errors are caused by inadequate production of language forms. As Nord (1997, p. 76) puts it linguistic errors are often due to deficiencies in the translator's source or target language competence.

\section{Methodology}

This research paper aims at studying the reasons that led senior students of English department in to commit mistakes in their translations and discussing how such reasons could be connected to linguistic and cultural competence and translation quality. The paper adopts a selective analytical qualitative method. Data was collected from three timedassessment scripts of 136 senior KKU students (level 7) during their actual assessment sessions of Translation 2. Therefore, we ended up with 136 samples of midterm and final scripts each plus 28 projects to study and analyze. Avoiding repetition as possible, samples of mistakes have been chosen selectively as for the most recurrent ones among others and the unusual mistakes, too.

\section{DISCUSSION \& FINDINGS}

To fulfill the methodology shown above, three timed-assessments were given to the students and we can divide them into three categories: A midterm paper, a group project paper and a final paper.

The midterm paper is a kind of official assessment given to the students of Translation 2 in the $1^{\text {st }}$ examination period and to be completed in one-hour session individually, having access to paper dictionaries only. It was about a literary text which narrates a theft story to be translated from English into Arabic (Figure 2).

\section{The Old-Clock Shop}

Christmas Eve had arrived. As last-minute shoppers were going home, a thick white sheet of snow laid over Lake City, USA. Yet the lights were still burning in the old-clock shop, as Ray, its old, deaf owner, still working on a clock.

He saw two men. The younger man remained at the door. The older man approached the counter with no sign of friendliness in his eyes. Ray turned to meet the shopper, but his wise eyes told him that this was not a shopper. Ray was able to hide his growing fear as he slowly pushed a notepad and a pencil across the counter.

He wrote on the notepad, "May I help you?" They both understood why he was there and why his friend remained at the door. Ray calmly wrote another message. "Have you come to pick up a clock or watch?" Then the man quickly looked at the watch on his wrist. "How much will you give me for this?" the man wrote. Ray noticed a little shame in the grey eyes looking at him. Ray gave him fifty-dollars. They both knew the watch wasn't worth that much. The old man left saying: "Merry Christmas". The message of 'Peace on earth, goodwill towards all' was felt by the three men who stood in the old-clock shop. 
On the other hand, the second assessment was a translation group project which is a kind of an official assessment given to the same patch of students to be completed in a week time. The week that the project was scheduled to be held in didn't include any other submissions or papers for other courses. It was chosen on purpose to hold the project in to ensure the students won't be distracted with other stuff which may affect the quality of their target texts or they take it as an excuse to ask for extending the submission deadline. Each group should comprise 4-5 students maximum where they chose to be together so it's not a random distribution from the instructor or a forced one. This has been done to ensure that each group of students are willing to work together and communicate to one another with no excuses for miscommunication matters. Each group chose a leader, translators and a proofreader. The project consists of 3 medium to long literary passages for different writers and, therefore, written with different styles (Figure 3). These passages meant to be rendered into English.

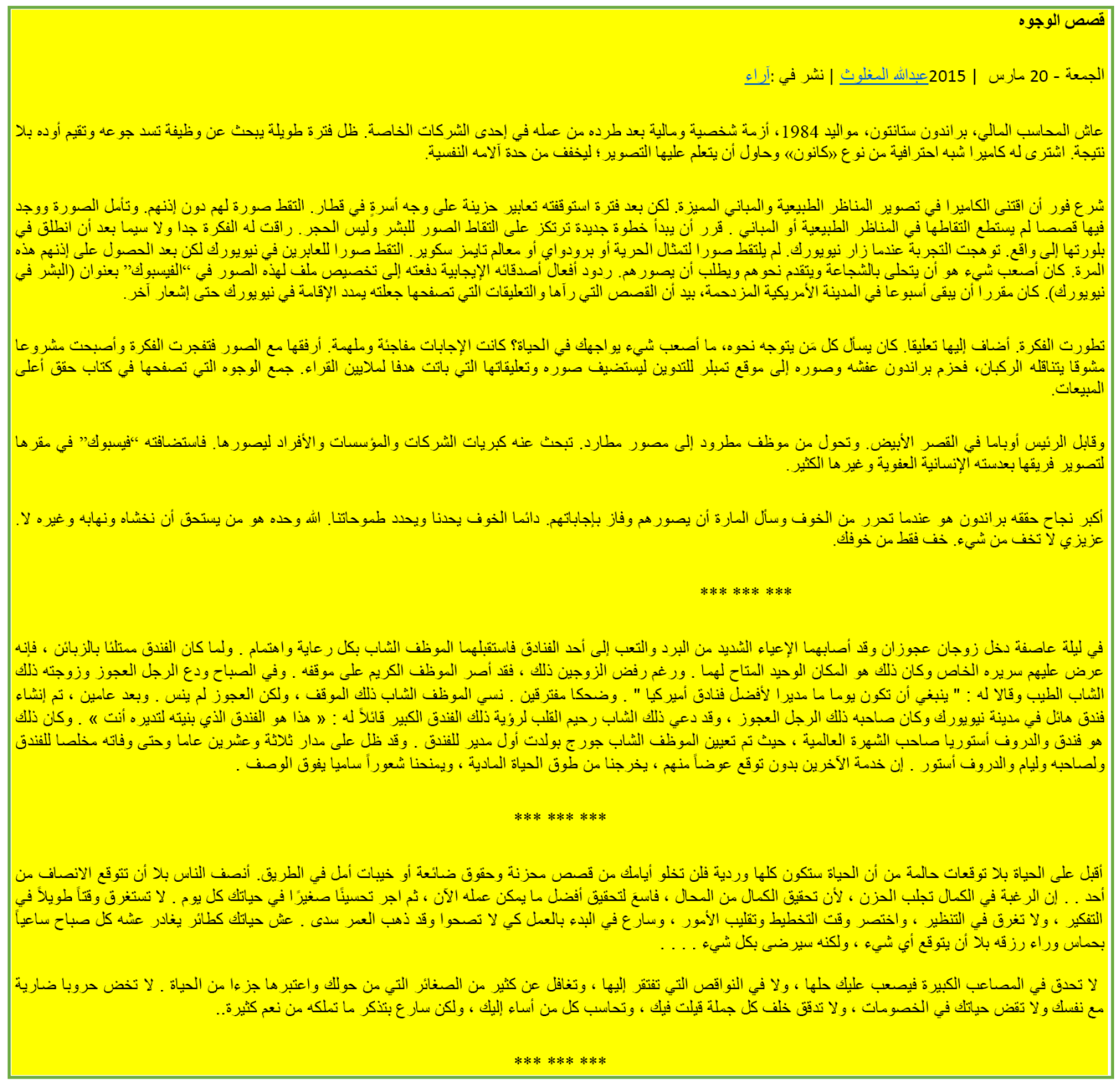

(Figure 3): Translation group project

The last type of assessment given was the final paper of the course. It is a kind of an official formal assessment given to the same patch of students to be completed in a two-hour session individually, having access to paper dictionaries only. The text is an informative description of Diriyah Season to be rendered into Arabic with some key words translated at the bottom (Figure 4). 
Diriyah is the historical site of the establishment of the first Saudi state and is considered the Jewel of the Kingdom. It embodies the soul of the nation's history, and the promise of its future. For hundreds of years, its cool mud-brick buildings have been a refuge for those seeking relief from the heat of the desert and a hub where communities can gather, share and grow together.

Located just minutes from Riyadh, Diriyah was founded on the banks of the Wadi Hanifah, surrounded by lush agricultural lands. As communities grew in Wadi Hanifah, Diriyah developed into a central gathering point in Najd Region.

Today, Diriyah Season is an unmissable set of international sports and entertainment events, happening at a UNESCO heritage sight, Diriyah, the birth place of the Kingdom of Saudi Arabia. Sports fanatics, entertainment seekers, foodies and shoppers, don't miss out on a month of energy, excitement, elegance, and memorable moments as the world comes to Diriyah!

A giant open-air family entertainment district for all ages - the spectacular Diriyah Oasis - will be created as part of the thrilling Diriyah Season. As a cultural and entertainment district, Diriyah Oasis reflects the rich heritage, unique architecture and affluent resources of Saudi Arabia and the region. It will feature carnival games and stalls, plus dining options to suit all tastes.

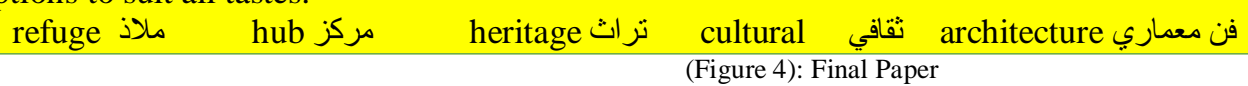

The same patch of students (136 seniors) taken the three assessments during semester 1 in the academic year 20192020, and their scripts were checked and marked then analyzed (all samples available in hard copies). This paper will not engage the marking criteria in the discussion as the main focus here is on the translation decisions taken by the students and how these could range from poor to acceptable -excellent choices and how this can be linked to linguistic and cultural competence. (Tables 1, 2, 3).

Starting with the midterm paper, the students were given a feedback session after checking their scripts to discuss their good as well as poor choices of decisions shedding light on the most repetitive and strange ones (Table 1). This session turned to be a hilarious one as the students were surprised by the poor, or sometimes funny, translation decisions they've taken to some parts of the text. The main reasons leading to such poor choices the students talked about to their instructor in the feedback session were time constraints and examination anxiety. They believed that if they would be given extra time and/or they were a bit relaxed, they may produce better pieces of target texts. 
TABLE 1

FEEDBACK ON MIDTERM PAPER

\begin{tabular}{|c|c|c|}
\hline ST & Poor TTs & Acceptable/Excellent versions of TTs \\
\hline 1- Christmas Eve had arrived & 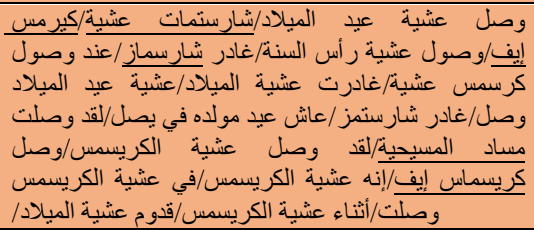 & 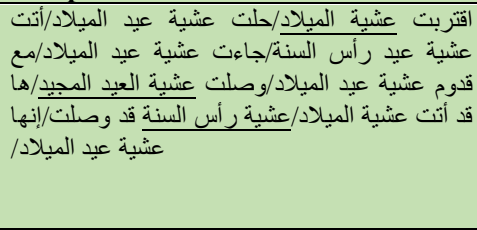 \\
\hline $\begin{array}{l}\text { 2- As last minute shoppers were going home, } \\
\text { a thick white sheet of snow laid over Lake } \\
\underline{\text { City, USA }}\end{array}$ & 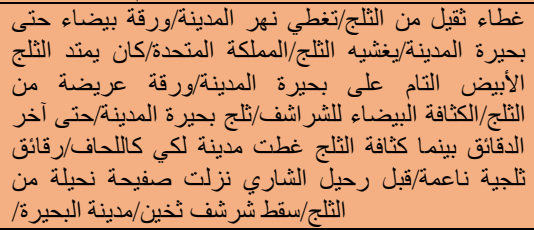 & 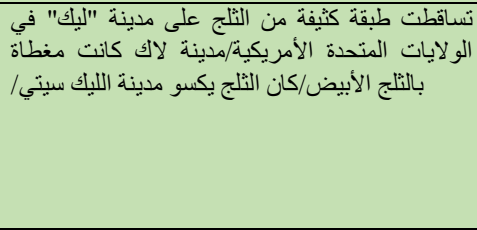 \\
\hline $\begin{array}{l}\text { 3- The lights were still burning in the old } \\
\text { clock shop }\end{array}$ & 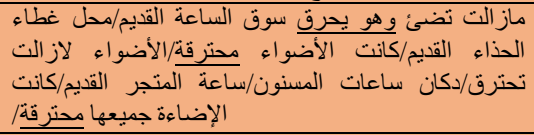 & 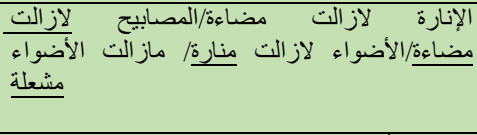 \\
\hline $\begin{array}{l}\text { 4- As Ray, its old, deaf, owner, still working } \\
\text { on a clock }\end{array}$ & 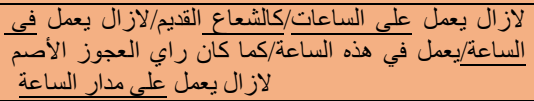 & 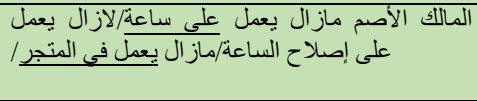 \\
\hline 5- The younger man remained at the door & 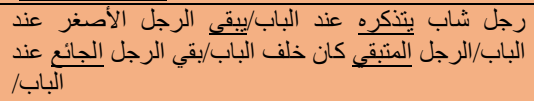 & 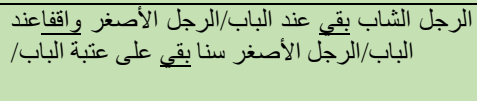 \\
\hline $\begin{array}{l}\text { 6- The older man approached the counter } \\
\text { with no sign of friendliness in his eyes }\end{array}$ & 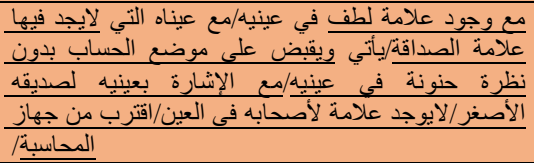 & 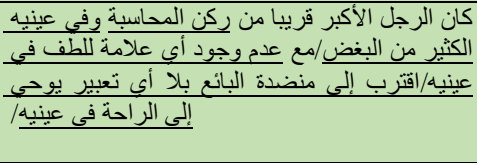 \\
\hline 7- Ray turned to meet the shopper & 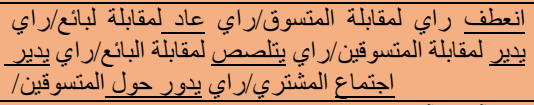 & 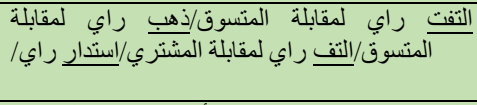 \\
\hline $\begin{array}{l}\text { 8- "Have you come to pick up a clock or a } \\
\text { watch?" }\end{array}$ & 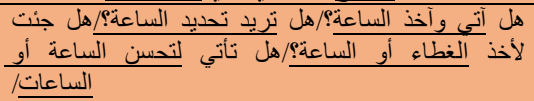 & 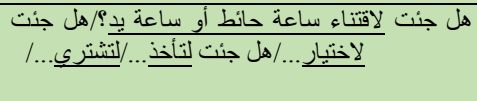 \\
\hline $\begin{array}{l}\text { 9- The old man left saying: } \\
\text { "Merry Christmas" }\end{array}$ & ماري كريسماس/الرجل المسن قال للبيسار عيد ميلاد ماري/ & عبد ميلاد مجيد/عيد ميلاد سعيد/عبد مجيد/عيد رأس سيد/ \\
\hline $\begin{array}{l}\text { 10- The message of 'peace on earth, goodwill } \\
\text { towards all' was felt by the three men who } \\
\text { stood in the old clock shop }\end{array}$ & 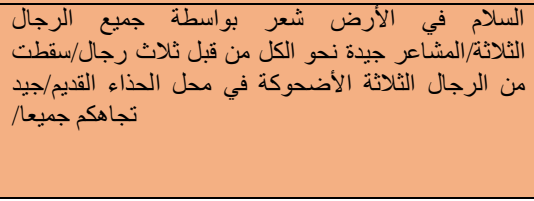 & 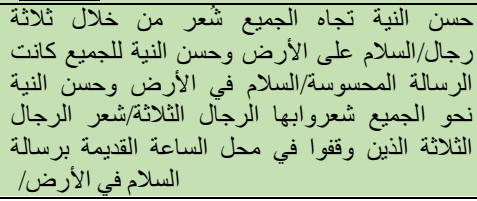 \\
\hline
\end{tabular}

Certainly, time is a big factor in any translation task, simple or complicated. We can see deadlines in big translation companies working with professional translators, in schools of translation managing projects and assignments of their students and we can even find some timed assignments in certain translation programs. In the field of translation time is a factor. This leads to one end that time is really a significant aspect affecting professional translators before novice ones (in our case students of translation). Nevertheless, $25 \%$ of the students given excellent target texts were taking the test in the same atmosphere as others, though.

It's good to acknowledge that throughout the semester, the students were put under three types of training on how to manage their timing while having a translation task in hand. First, in the opening class of the course, they were given some tips in writing about how to achieve time management and started to apply them in every single class that followed. In classes, the students were given texts to translate while the instructor counting the time on the stop watch. The timing was divided in a certain criteria where 3-4 minutes allotted for reading and comprehending the text, and underlining new terms. Then students were stopped to determine the brief of the text: register, tense and genre in two minutes. This helped a lot in getting the right choices to translate the text. Then, five minutes counted for looking the new terms up in the dictionary or to guess their meanings from the context. Then, they started the actual translation by given them an average 3 minutes per line in the first 4 classes and then 2 minutes per line until they reached 30 seconds to complete a line in a text by the end of the semester.

The second strategy has actually started after the midterm paper since some students still complaining of time limitations. The instructor was given an interpretation-like class where the students orally translate line by line the ST after their instructor and given 5 minutes at the end to articulate the text all together. The students were very pleased about this strategy in particular and they showed that in writing to the instructor upon asking them to write their comments casually and anonymously on the course later at the end of the semester (copies available). 
Nonetheless, the big question is: Can time constraints really push students to produce poor unusual mistakes such as the ones shown in (Table 1)? Is it really time limitations that make a student to translate "Marry Christmas" which is a very well-known phrase into " or " Is it timing or cultural incompetence? When a student used "as a translation to "a thick white sheet of snow laid over Lake City, USA", is it because of timing or linguistic incompetence? What is more logical to you?

(Madkour, 2018, p. 99) has defined cultural competence as: "the awareness that develops out the experience of culture“. It has become clear that some unusual mistakes produced to a text which is in the same level of the students and, perhaps rated by most of them as easy to medium in difficulty, are not a consequence of time constraints since $25 \%$ of the students under the same conditions produced even excellent target texts and left the examination room in time! Rather, it's a matter of lacking competence either culturally or linguistically as shown in (Table 1). Being ignorant with a famous cultural and religious phrase such as "Marry Christmas" which can be heard in movies, videos to name a few is showing that even if students were given longer time, they won't produce the right version of translation and they will give the exact mistaken translation to that segment because simply they aren't aware of the right meaning of the cultural segment in the first place.

TABLE 2

FEEDBACK ON TRANSLATION GROUP PROJECT

\begin{tabular}{|c|c|c|}
\hline ST & Poor TT & Acceptable/Excellent versions of TTs \\
\hline 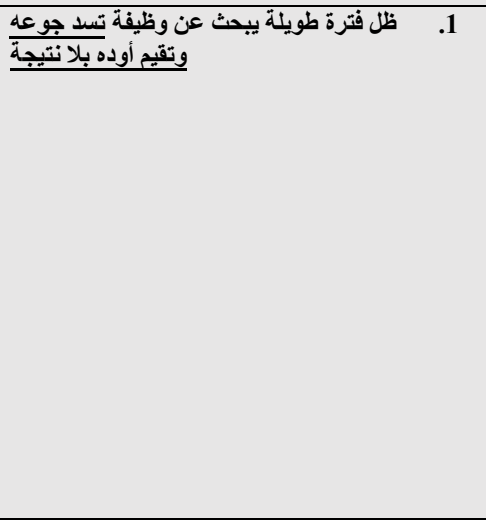 & NIL & $\begin{array}{l}\text { He was looking for a job that would fill } \\
\text { his hunger and get him back on his feet, } \\
\text { but it was a dead end/to fill his hunger } \\
\text { and support his life/to fill his hunger } \\
\text { and help him/he kept for long time } \\
\text { looking for a job to make a living } \\
\text { without a result/looking for a job which } \\
\text { helps him with the difficulties of life/to } \\
\text { help him to be independent again/to } \\
\text { satisfy his hunger and mend himself/to } \\
\text { support himself/keeps him barely } \\
\text { alive/to make a living/looking for a job } \\
\text { that can keep his soul and body } \\
\text { together/to get over life difficulties/to } \\
\text { earn his living/helps him in his life/to } \\
\text { survive }\end{array}$ \\
\hline 2. ليخفف من حدة آلامه النفسية & NIL & $\begin{array}{l}\text { To ease his psychological pain/ to } \\
\text { relieve/to alleviate/to intensify his } \\
\text { emotional distress/to lessen/to reduce } \\
\text { his psychological struggles/to } \\
\text { diminish/to decrease }\end{array}$ \\
\hline 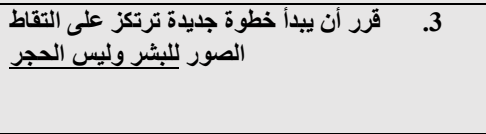 & Based on photographing people not rocks & $\begin{array}{l}\text { Capturing pictures for humans not for } \\
\text { the inanimate/ taking pictures for } \\
\text { humans not non-living objects/of } \\
\text { humans not non-humans }\end{array}$ \\
\hline 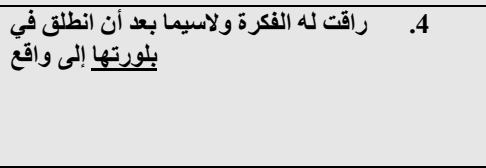 & $\begin{array}{l}\text { He liked the idea especially after he started to } \\
\text { crystalize it into reality/ }\end{array}$ & $\begin{array}{l}\text { This idea impressed him a lot especially } \\
\text { after he turned its essence into reality/ } \\
\text { after he set out to practice it/he started } \\
\text { to convert it into reality/after he applied } \\
\text { it into reality/turned it into a real }\end{array}$ \\
\hline 5. التقطورأ للعابرين في نيويورك & New York passengers/ & $\begin{array}{l}\text { He took pictures of the passers-by in } \\
\text { New York/capturing pictures for } \\
\text { random people/he took photos of the } \\
\text { New Yorkers/of New York's } \\
\text { pedestrians/the people walking there/for } \\
\text { the transient }\end{array}$ \\
\hline 6. أصبحت مشروعاً مشوقاً يتناقله الركبان & $\begin{array}{l}\text { Exciting project between passengers/commuting } \\
\text { stirrups/carried by stirrups }\end{array}$ & $\begin{array}{l}\text { Became an interesting project that was } \\
\text { shared among people/an interesting } \\
\text { project narrated by people } \\
\text { everywhere/most people have been } \\
\text { talking about/ spread among people/that } \\
\text { everyone was talking about/ that } \\
\text { outspreads among people/ exchanged by } \\
\text { people/travels by people/it became the } \\
\text { topic that people talk about/became a } \\
\text { popular project/the idea became word of } \\
\text { mouth/very famous/spread among all }\end{array}$ \\
\hline فحزم براندون عفشه وصوره إلى موقع تمبلر & $\begin{array}{l}\text { Brandon picked up his furniture and photos to } \\
\text { take them to Tumblr/he packed his baggage and } \\
\text { pictures/he backing his packs for blogging } \\
\text { Templar/packed his throne and his image to the } \\
\text { Templar }\end{array}$ & $\begin{array}{l}\text { Brandon gathered his ideas and pictures } \\
\text { to Tumblr/he collected all his tools and } \\
\text { photos to Tumblr blogging site/he } \\
\text { packed his stuff and images to } \\
\text { Tumblr/he moved his stuff and pictures }\end{array}$ \\
\hline
\end{tabular}




\begin{tabular}{|c|c|c|}
\hline & & $\begin{array}{l}\text { to Tumblr/he packed his pictures/he } \\
\text { started his project on the blogging } \\
\text { website Tumblr/Brandon created a blog } \\
\text { on Tumblr }\end{array}$ \\
\hline 8. تحول من موظف مطرود إلى مصور مطارد & $\begin{array}{l}\ldots \text { to a stalker photographer/into a wanted } \\
\text { photographer/he was hinting by people instead of } \\
\text { hunting them }\end{array}$ & $\begin{array}{l}\text { He turned from a fired employee to a } \\
\text { desirable photographer/he became } a \\
\text { famous photographer after being a fired } \\
\text { employee/after he was fired he became } \\
\text { a famous photographer/ /he was tuned } \\
\text { from a fired employee into a popular } \\
\text { photographer/turned from a fired } \\
\text { employee to a paparazzo/transformed } \\
\text { from being a dismissed employee to a } \\
\text { striving photographer/to a chased } \\
\text { photographer/he turned from a } \\
\text { dismissed employee to a required } \\
\text { photographer }\end{array}$ \\
\hline 9 9 أصبر الموظف الكريم على موقفه & $\begin{array}{l}\text { He insisted them to accept his offer/ insisted on } \\
\text { his attitude/insisted on his stand/he insisted about } \\
\text { his reaction/ insisted about his kindness and } \\
\text { behavior }\end{array}$ & $\begin{array}{l}\text { The generous clerk insisted/insisted on } \\
\text { his offer/despite..., the employee dug } \\
\text { in his heels/ insisted on his position }\end{array}$ \\
\hline 10. أقبل على الحياة بلا توقعات حالمة & $\begin{array}{l}\text { He came to life without any dreaming } \\
\text { expectations }\end{array}$ & $\begin{array}{l}\text { Move forward to life without dreamy } \\
\text { expectations/accept life without dreamy } \\
\text { expectations/move towards life/come to } \\
\text { life without/live life with no } \\
\text { dreamy/proceed in life /face life } \\
\text { without/approach life without }\end{array}$ \\
\hline 11. & $\begin{array}{l}\text { Do not spend your life in discounts/do not spent } \\
\text { your life for opponents/in the discounts }\end{array}$ & $\begin{array}{l}\text { Don't go through fierce wars with } \\
\text { yourself, spend your life in } \\
\text { arguments/don't fight fiercely with } \\
\text { yourself and don't spend your life with } \\
\text { the opponents/do not spend your life in } \\
\text { rivalries/do not spend your life in } \\
\text { disputes/don't spend your life in } \\
\text { quarrels/in fights/in antagonisms/in } \\
\text { conflicts/in adversaries }\end{array}$ \\
\hline
\end{tabular}

The third assessment given was the final paper which demonstrates a well-known cultural district to any Saudi citizen, Diriyah. The text talked about the historical position of the place and the well-advertised Diriyah Season (Figure 4).

TABLE 3

FEEDBACK ON THE FINAL PAPER

\begin{tabular}{|c|c|c|}
\hline ST & Poor TTs & $\begin{array}{lll}\text { Acceptable/Excellent versions of } \\
\text { TTs }\end{array}$ \\
\hline $\begin{array}{l}\text { 1- Diriyah is the historical site of the } \\
\text { establishment of the first Saudi state }\end{array}$ & 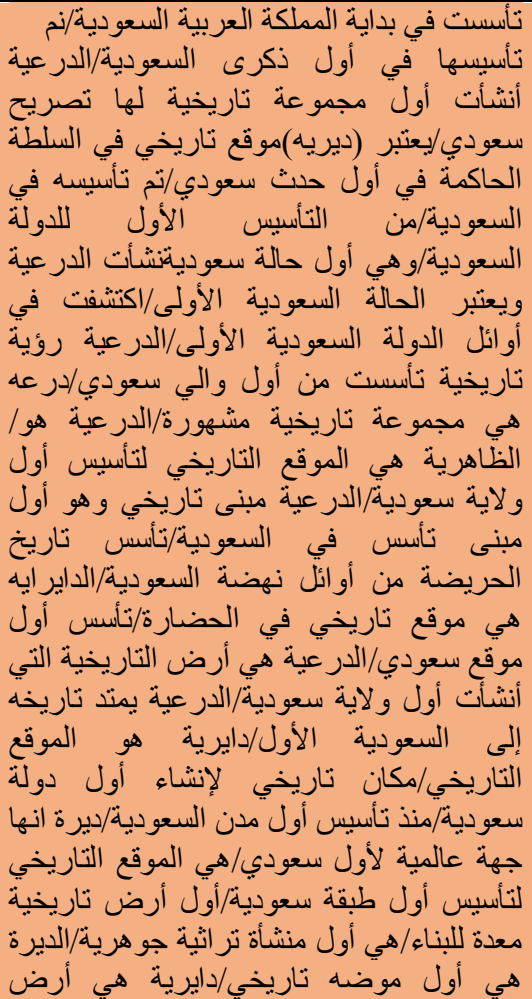 & 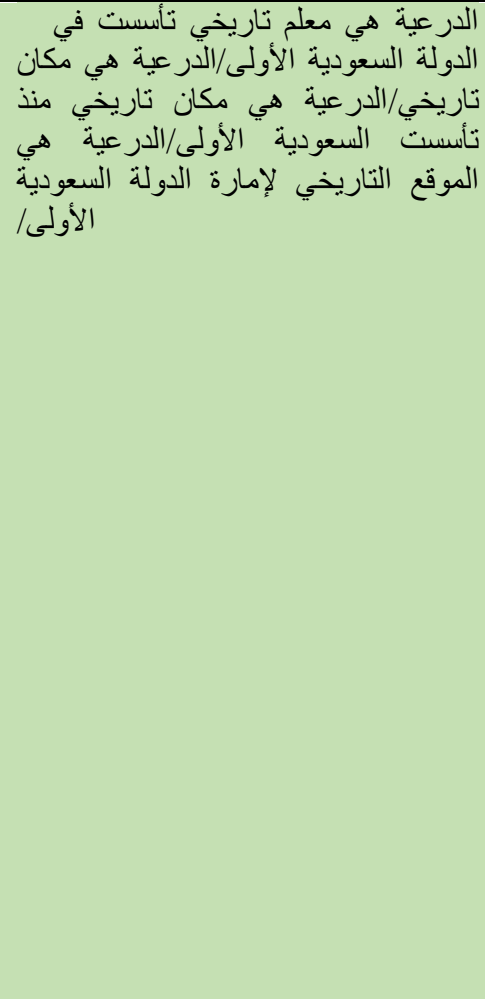 \\
\hline
\end{tabular}




\begin{tabular}{|c|c|c|}
\hline & 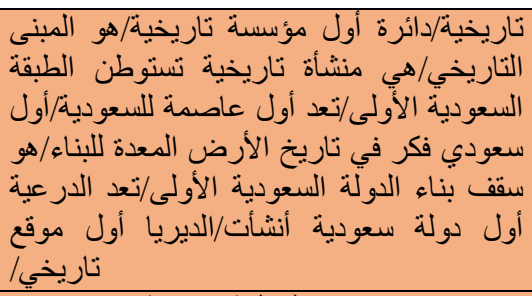 & \\
\hline 2- considered the Jewel of the Kingdom & 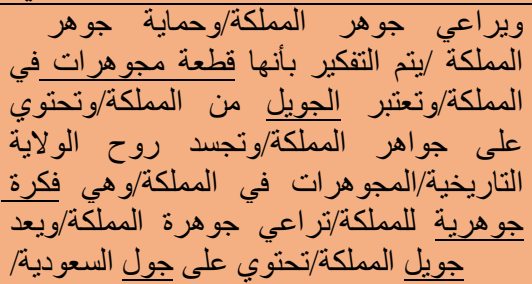 & 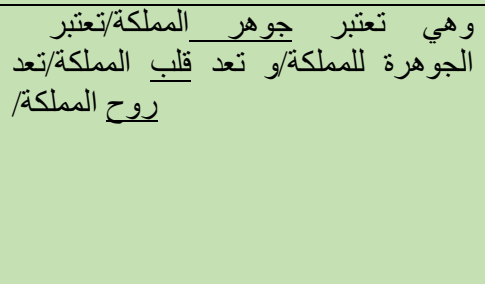 \\
\hline 3- its cool mud-brick buildings & 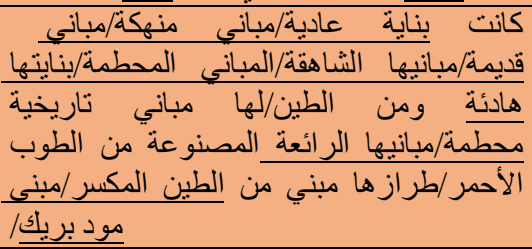 & 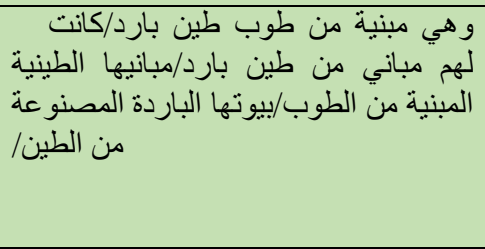 \\
\hline 4- on the banks of the Wadi Hanifah & 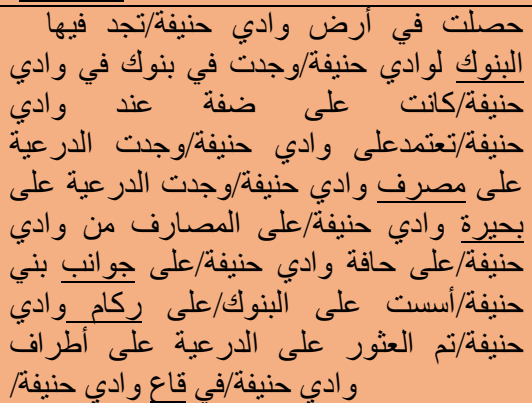 & تأسست في ضلى وادي حنفةة/على ضي ضفة واديفة/مطلة حنيفة/ \\
\hline $\begin{array}{l}\text { 5- happening at a UNESCO heritage sight, } \\
\text { Diriyah }\end{array}$ & 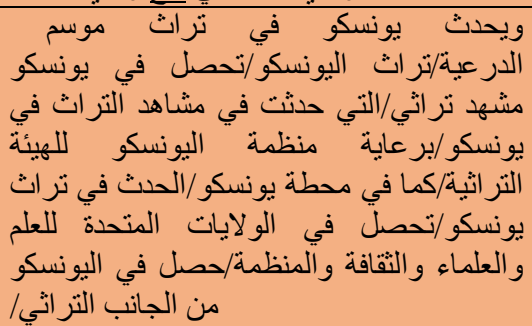 & 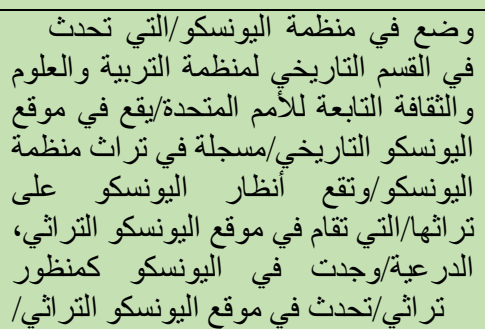 \\
\hline $\begin{array}{l}\text { 6- A giant open-air family entertainment } \\
\text { district for all ages }\end{array}$ & 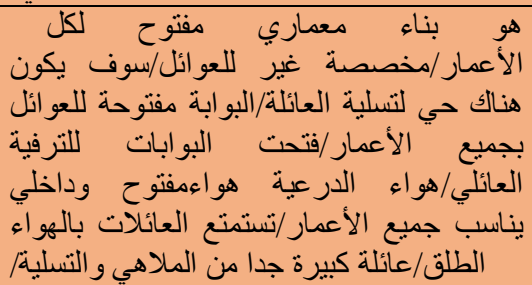 & 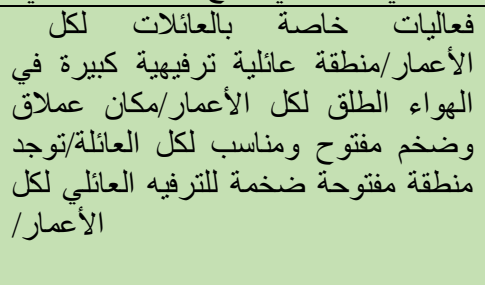 \\
\hline $\begin{array}{l}\text { 7- affluent resources of Saudi Arabia and the } \\
\text { region }\end{array}$ & 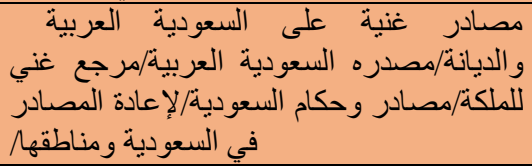 & غني بالموارد في المي المملكة/مصنادر المنية للمكة والمنقىة/ \\
\hline
\end{tabular}

At the time period of the test, the Diriyah Season was launched and, therefore, visited by many renowned people and got good coverage on TV and by most social media influencers in Saudi Arabia. We found it a good idea to give such a topic to the students so they would be definitely familiar with. Surprisingly, Diriyah has been rendered as ، الحريضة ، درة ، in some of the scripts (please refer to example 1, Table 3). Such poor choices for the well-known cultural and historical place show the effect of cultural negligence and incompetence on the TTs of the students. The poor versions of translations given to this sentence foster the notion of the importance of cultural competence to produce translation quality as an output. Unlike linguistic incompetence, cultural incompetence is not forgivable and cannot be excused in most of the cases. 
Another example of cultural incompetence produced here is the second part of the first example (the first Saudi state). This phrase is widely mentioned in school's curricula of Saudi students yet still be translated as quite inacceptable versions such as: أول تصريح سعودي ، أول طبقة سعوبية ، أول ولاية سعودية.

Some sentences have undergone lexical and linguistic mistakes. Let's take the example of (mud-brick buildings) which is assumed to be known by most of the students because they can see them in Saudi and Gulf TV series, heard about them from the old members of families, find out about them in books and museums and some of these buildings still available in villages and outskirts. Most of the mistakes in translating this segment is that the student have described it in their own imagination and were very free in their translations such as: هائة ، منهكة ، عادية ، معطمة ، شاهقة ،

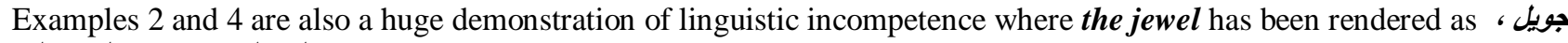
هe students focused on the denotative meaning of the word only and ignored the context, and the word the banks was rendered as بنوي ( Such mistakes affect the quality of the translation desperately.

On the other hand, the same examples of the text have been rendered in a smart way by other students whom we think are strong linguistically and therefore culturally (as you can see in Table 3). They comprise about $40 \%$ of the whole samples. Those students show high level of linguistic and cultural competence, their sentences flow smoothly, the meaning is clear and the text in general is coherent. They can get use of the context to provide closer meanings for what the texts they work on.

\section{Pedagogical Insights}

It's worth saying that, yes classroom is not the only place to master translating but it is the first stage most of the time translators start with. In the classes of translation, students are given theortitical and practical sides of the discipline and see different types of texts. What we want to say here is that the classroom can be a more productive place if we become able to functionalize it well.

That is to say, first, institutions of English and Translation should put clear criteria for admitting students to their programs. Language and translation require having good knowledge of English and culture in the first place. Then when students enrolled in the program they can build on the good base they have. Institutions shouldn't tolerate this as it's the first brick in the whole learning process.

By the time those linguistically good students reach level 6, 7 and 8 where they are expected to study Translation courses, they can manage translating different genres more than others with low levels of competence. They can, presumably, get more of their instructors and/or have the tendency to read and practice more.

What is even better is when those students have to choose their path after they got the grounds of the language. So maybe after completing level 4 they can choose their major either translation studies, literature or linguistics, what so ever, and start studying intensively what they have chosen. That means they are passionate about the major and would like to take it forward. This would make huge difference to the students and the outputs of the programs in the market later on.

As instructors of translation, our aim is to teach a reasonable number of students in which we can check their progress gradually and give personal tutorials more often. We need to spot the translation problems for all of them individually right from the beginning so they can work on them and fix the gap. With packed-classes of students, it becomes impossible to achieve such a goal.

Good and fair admissions criteria, reasonable class size, passionate students of translation are three crucial factors that can elevate the quality of teaching and the outputs of translation programs and their alumni.

\section{CONCLUSION}

To sum up, we can say that linguistic and cultural incompetence is a state of having some problems in comprehending a text in its context which affect the quality of the TTs negatively. Incompetent students culturally or linguistically tend to provide peculiar translations that can be disastrous sometimes. As a matter of fact, in most of the scripts checked, if the students made recurrent linguistic mistakes in grammar or structure or word choice they tend to produce mistakes also in the cultural segments of the text. In other words, we as researchers believe that culture is beyond language as any language can be a part of a culture and in what we have seen the students who produced linguistic mistakes failed also in rendering the cultural parts correctly and it was impossible for most of them to understand the cultural aspects of some of the sentences because simply they couldn't get the easier linguistic parts correctly.

\section{RECOMMENDATIONS}

In the light of the aforementioned discussion of results, it is recommended to teach translation strategies comprehensively in translation courses and to pay more attention on students' perception of the power of culture in transferring meaning from the ST (source text) to the TT (target text) during classroom activities in order to build their translation competence. 
From a pedagogical viewpoint, in order for students to promote their translation competence, their level of linguistic competence must be developed. One of the most important actions to be taken is to teach students dictionary skills and searching strategies. Students should be taught how to use different dictionaries (i.e. glossaries, thesaurus, etc.) which will be reflected on their translation competence. They should be encouraged to use collocations, idiomatic expressions and words chunks in order to enhance their translation competence.

More time should be allocated to translation classes and more challenging topics (i.e. linguistically, culturally, etc.) should be incorporated. In addition, more group discussions should take place in the classroom. Group work can increase motivation and reduce the affective filters (i.e. stress, anxiety, low self-esteem, etc.) (Krashen, 1981). Additionally, flipped classroom techniques of translation could be used to improve students' translation competence. For instance, translation examples can be given to students as home activity, and then students participate in group discussions working on texts similar to the examples they have been previously introduced to at home. Additionally, it is recommended to encourage peer review inside the classroom. Peer review could be one of the significant techniques that can boost linguistic and cultural competence and consequently translation competence. Wang and Han (2013) assert that peer review helps students overcome different translation problems.

Additionally, content-knowledge competence and monitoring competence should be highlighted for translation students. The exposure to various contexts is an affective procedure to improve content-knowledge competence while the ability to work on the translated texts for editing and improving the translation could help students in enhancing their monitoring competence. Teachers need to give comprehensive and task-based oriented feedback to students in time. They should, in addition, encourage the students to employ strategies selection exercises, comprehensive evaluation of the produced target texts, and reflection on the word choice.

\section{REFERENCES}

[1] Baker, M. (1992). In Other Words, London \& New York: Routledge.

[2] Baker, M. (ed). (2001). Routledge Encyclopedia of Translation Studies, London \&New York: Routledge.

[3] Bassnett, S., \& Guire, M. (1991). Translation Studies. London: Longman.

[4] Bassnett, S., \& Lefevere, A. (2016). Translation, rewriting and the manipulation of literary fame. New York: Routledge.

[5] Bhabha, H. (1994). The location of culture. London: Routledge.

[6] Blum-Kulka, S. (1986). "Shifts of cohesion and coherence in translation." Interlingual and Intercultural Communication: Discourse and Cognition in Translation and Second Language Acquisition Studies, 17-35

[7] Chomsky, N. (1965). Aspects of the theory of syntax. Cambridge, MA: MIT Press

[8] Hartono, R. (2017). Pengantar Ilmu Penerjemahan.Semarang: Cipta Prima Nusantara.

[9] Hatim, B. (2001).Teaching and researching translation. Malaysia: Pearson Education.

[10] Hewson, L., \& Martin, J. (1991). Redefining translation. The variational approach. London and New York: Routledge.

[11] Jibreel, I., Al-Abbasi, A., and Al-Maqaleh, A. (2017). The Relationship between Translation Strategies Awareness and Students' Translation Quality Journal of Applied Linguistics and Language Research Vol 4, No 6. Retrieved on January 12 , 2020 from https://pdfs.semanticscholar.org/6c3b/9df95e80e1858e869a9f20866a58e74bfa4c.pdf.

[12] KRASHEN, S. (1981). Second Language Acquisition and Second Language Learning. Oxford: Pergamon Press.

[13] Li, D. (1999). 'Reflective Journals in Translation Teaching', Perspectives: Studies in Translatology, 6(2): 225-34

[14] Madkour, M. (2018). The Impact of Culture and Intercultural Competence on the Performance of Students in Translation. RAIS Conference Proceedings - The 11th International RAIS Conference on Social Sciences. Retrieved on January 12, 2020 from SSRN: https://ssrn.com/abstract=3303360 or http://dx.doi.org/10.2139/ssrn.3303360.

[15] Malyuga, E. N., Krouglov, A., \& Tomalin, B. (2018). Linguo-cultural competence as a cornerstone of translators' performance in the domain of intercultural business communication. XLinguae, 11(2), 566-582. Retrieved on January 12, 2020 from https://doi.org/10.18355/XL.2018.11.02.46.CrossRefGoogle Scholar.

[16] Metwally, A. (2019). Foreignising versus domesticating translations of Arabic colour-related expressions. Journal of Language Teaching and Research 10(2): 383-390. Retrieved on September 20, 2019 from http://www.academypublication.com/ojs/index.php/jltr/article/view/jltr1002383390.

[17] Newmark, P. (1988). A Textbook of Translation. New York: Prentice-Hall.

[18] Nord, C. (1997). Translation as a purposeful activity. Manchester: St Jerome.

[19] Popescu, T. (2011). Linguistic competence vs. Translation competence: A pedagogic approach. In FLTLAL 2011 Proceedings/1st International Conference on Foreign Language Teaching and Applied Linguistics May 5-7 2011 Sarajevo. Sarajevo: International Burch University, ISBN 978-9958-9965-9-7, pp.1183-1189.

[20] Pym, A. (1992). Translation error analysis and the interface with languageteaching. Retrieved on January 12,2020 from http://www.tinet.cat/ apym/on-line/training/1992_error.pdf.

[21] Rafieyan, V. (2016). Relationship between Cultural Intelligence and Translation of Culture-Bound Texts, Journal of Applied Linguistics and Language Research, 3(3), 2016, pp. 173-184. www.jallr.com ISSN: 2376-760X. Retrieved on January 12, 2020 from https://www.semanticscholar.org/paper/Relationship-between-Cultural-Intelligence-and-ofRafieyan/e82234936495eacd768390272f8941c2e82d36d9.

[22] Rahmatillah, K. (2013). Translation errors in the process of translation. Journal of English and Education, 7(1), 14-24 Retrieved on January 12, 2020 from https://media.neliti.com/media/publications/222302-translation-errors-in-the-process-of-tra.pdf.

[23] Reiss, K., \& Vermeer, H. J. (1984). Groundwork for a general theory of translation. Tubingen: Niemeyer.

[24] Sofer, M. (1998). The Translator's Handbook (2nd ed). Rockville, Maryland: Schreiber Publishing, Inc.

[25] Spolsky, B. (1972). What does it mean to know a language? In K. Croft (Ed.) Readings on English as a Second Language (pp. 26-42). Cambridge, Mass: Winthrop Publishers 
[26] Venuti, L. (1995). The translator's invisibility: A history of translation. Abingdon, Oxon: Routledge.

[27] Venuti, L. (2017). (Ed.). Teaching translation: Programs, courses, pedagogies (1st. ed.). New York: Routledge.

[28] Vermeer, H. (1978). A framework for a general theory of translation. Heidelberg: Heidelberg University.

[29] Wang, K. \& Han, C. (2013). Accomplishment in multitude of counselors: Peer feedback in translation training. The international Journal for Translation \& Interpreting Research. 5(2) Retrieved on January 12, 2020 from http://www.transint.org/index.php/transint/article/view/213/131.

[30] Wongranu, P. (2017). Errors in translation made by English major students: A study on types and causes. Kasetsart Journal of $\begin{array}{llllllll}\text { Social Sciences, } & 38 . & \text { Retrieved } & \text { on } & \text { January } & 8, & 2020 & \text { from }\end{array}$ file://C:/Users/USER/Downloads/Errors_in_translation_made_by_English_major_studen.pdf.

Safiah Ali M. Asiri was born in Abha - Saudi Arabia in $17^{\text {th }}$ June 1985. Asiri has got the degree of Bachelor of Arts in English Language, King Khalid University - Abha - Saudi Arabia in 2007 and has Master of Arts in Arabic/English translation with Merit, University of Salford - United Kingdom in 2011. She worked as Teaching Assistant for two years then in 2009 she got a scholarship to pursue her education in the UK and returned home in 2011 to become a Lecturer of translation at King Khalid University until present. She worked in the college in different committees such as: Students' Affairs, Students' Activities, Curricula and Plans, Quality, Measurement and Accreditation. She took some positions as the Supervisor of the English department and the Supervisor of the Academic Services Unit. Current research interests are: pedagogy and translation teaching, localization, new trends in translation studies. Ms. Asiri is an Associate Member in the American Translators Association ATA and a certified translator by the CTP program.

Amal A. Metwally, $\mathrm{PhD}$, is currently a lecturer of linguistics and translation at faculty of languages and translation, King Khalid University, Saudi Arabia. She received her PhD in linguistics from Al-Azhar University, Cairo, Egypt. She has published papers in linguistics, English language teaching and learning, and translation. Her research interests include applied linguistics, translation and culture, technology in language instruction and language learning and computational linguistics. She is a certified TOFEL Trainer and a certified IELTS Trainer. 